DOI https://doi.org/10.18551/rjoas.2017-09.32

\title{
RICE PRICE VOLATILITY IN EAST JAVA
}

\author{
Wati Rustida Yulivia Eko* \\ Graduate School, Faculty of Agriculture, University of Brawijaya, Indonesia
}

Anindita Ratya, Setiawan Budi

Department of Socio Economics, Faculty of Agriculture, University of Brawijaya, Indonesia

*E-mail: rustida.yulivia@gmail.com

\begin{abstract}
The purpose of the research is analyzing the volatility and volatility spillover of monthly price of paddy at the level of farmers and consumers in 2010-2016. ARCH/GARCH used to analyze volatility and GARCH BEKK-model is used to analyze the volatility spillover. The results of the analysis show that price volatility at the farmer level is very high (extremely high volatility), price volatility at the consumer level is low (low volatility), and volatility spillover does not occur between the farmers and the consumers market. The need to guarantee an effective floor price as well as information disclosure related to the market commodity prices so that the pattern of prices transmission among interrelated markets can be symmetrical.
\end{abstract}

\section{KEY WORDS}

Price, volatility, rice, market.

Nominal prices of agricultural commodities are generally more volatile than nonagricultural commodities (Tomek and Robison, 1990). The cause was a shock on production due to natural factors such as climate change, pests, and diseases (Banterle and Vandone, 2013) as well as supply and demand in the short term that is inelastic (Demeke et al., 2012). FAO et al., (2011), explained that the onset of price volatility or price variations will not be a problem when the price moves subtly and price trend shows a typical seasonal pattern. However, the variation of the price will be a problem when the price variations occurred too large and could not be anticipated by the market (Donmez and Magrini, 2013).

There are several factors that can be varying the prices of rice. On the demand side, price variations are caused by ups and downs of people's income (Gilbert and Morgan, 2011) and the price of fuel oil (Demeke and Balie, 2016). On the supply side, the availability of rice stocks affects the occurrence of the price variations are generally caused by natural shock factors such as weather and an uncertain climate, pests and diseases, and natural disasters (Kalkuhl et al., 2013).

The fluctuated price condition of rice led to higher risks and uncertainties faced by farmers or consumers (Assefa et al., 2015). From the consumer side, the high rice prices and volatile became a threat for the poor especially in the developing countries (Serra and Gil, 2012) such as Indonesia are predominately consuming rice as a major commodity in meet the needs of calories (Badan Penelitian dan Pengembangan Pertanian, 2012). When the price of rice goes up, then the purchasing power of society in meeting the needs of calories will decrease (Badan Pengkajian dan Pengembangan Kebijakan Perdagangan, 2015). So, fluctuation faced in the high level of price will automatically be able to increase the number of poverty rates.

Irawan (2007) explained that price fluctuations can harm the farmers because the lack of sales management to get a more favorable selling price in the right time. Prices at the farmers level are likely to be determined by the tradesman or middleman because farmers have low bargaining positions in determining price and only acts as a recipient of the price (price takers) (Jamal et al., 2006). Farmers often have limited access information about the price movement in the market. 
The price received by the farmers is directly proportional to the income that he received. Low grain prices and volatile impact on the decrease of well-being level of farmers. Without adequate welfare, farmers as producers will lose the incentive to produce because of the magnitude of the risks faced by farmers due to the uncertainty of the price. So the farmers as producers can eventually reluctant to plant rice or even switching production to other commodities which are more profitable. This condition can interfere with the level of food availability and food security in the future. Thus, the purpose of the research was to analyze the present price volatility of farmers and consumers, as well as analyze the volatility spillover between the consumer market and farmers market.

\section{MATERIALS AND METHODS}

The data used is the price of harvested dry grain at the level of farmer and rice price at the level of consumer from January 2010 until December 2016 in Jember District, Malang District and Kediri District to represent the production of East Java based on the use of irrigation technical (surplus area), the technical and not technical irrigation (balance area), as well as not technical irrigation (deficit area). The following methods are used to analyze volatility and volatility spillover:

1. Stationary Test, selection of the best ARMA order and the test of ARCH:

Time series data that will be analyzed must be stationary (Ajija et.al, 2011). Data that has been stationary for each subsequent price variable being estimated or prediction Autoregressive Moving Average (ARMA) model using the method of trial error. The best model of ARMA has criteria, among others, all significant parameters coefficients (probability $<0.05$ ) with the smallest value of the standard error of a regressor (Ekananda, 2016). Having obtained the best model of ARMA, the next step is testing the presence of $A R C H$. Test of ARCH (ARCH effect) can be done with ARCH-LM test (Connor and Keane, 2011). This test is done to make sure that the value of the variance of the error does not have the same variance (heteroskedasticity).

2. Volatility Analysis:

Behavior of Volatility Analysis. A new method used in analyzing the data time series well-known as Autoregressive Conditional Heteroskedasticity (ARCH) model. The ARCH model allows the occurrence of shocks in the future period to influence the current volatility positively. While the GARCH model generalizes ARCH model which the GARCH model does not only allow the previous shocks, but also the previous volatility that affects current volatility (Connor and Keane, 2011).

$$
\begin{aligned}
& \sigma^{2} P P=\alpha_{0}+\alpha_{1} \varepsilon^{2} P P_{t-1}+\beta_{1} \sigma^{2} P P_{t-1}+\varepsilon_{t} \\
& \sigma^{2} C P=\alpha_{0}+\alpha_{1} \varepsilon^{2} C P_{t-1}+\beta_{1} \sigma^{2} C P_{t-1}+\varepsilon_{t}
\end{aligned}
$$

Where, $\sigma^{2}$ is the response variable (dependent) at time $(t)$ or current residual diversity; $\alpha_{0}$ is a constant, $\varepsilon_{t-1}^{2}$ is the ARCH/Volatility in the previous period; $\alpha_{1}, \beta_{1}$ is a coefficient of estimation; $\sigma_{t-1}^{2}$ is $\mathrm{GARCH} /$ residual diversity of the previous period; $P P$ is the price of harvested dry grain at the level of farmers, $C P$ is the price of rice at the consumer level; and $\varepsilon_{t}$ is a the error term factor in period to $t$.

According to Lipetit (2011), the sum of the estimated coefficients $\alpha_{1}+\beta_{1}$ on each model indicates the level of volatility. So, the volatility can be known by looking at the values $\alpha_{1}+\beta_{1}$. In this case, $\alpha$ is the value of ARCH and $\beta$ is the value of GARCH. Where $\alpha_{1}+\beta_{1}<1$ shows that the volatility is low (low volatility), $\alpha_{1}+\beta_{1}=1$ shows the volatility that occurred is high (high volatility) and $\alpha_{1}+\beta_{1}>1$ shows the volatility that occurred is very high (extremely high volatility).

The Measurement of Annualized Volatility. Here's how to calculate the annualized volatility according to Kant (2011), Ledebur and Schmitz (2012); and Singh and Kumar (2015). 


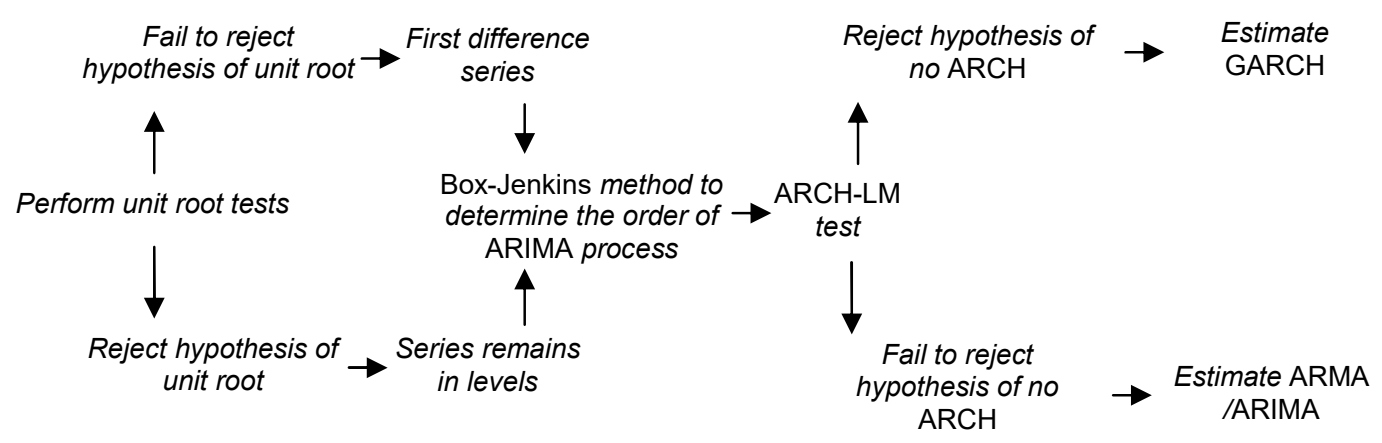

Figure 1 - Flowchart of methodology of calculating conditional volatility

(Moledina et al., 2004)

Measuring price changes in the market by calculating the log of a ratio $\left(P h_{j}\right)$ on the price $\left(P_{2}\right)$ of the current price $(t)$ to the previous price $\left(P_{1}\right)$.

$$
\mathrm{Ph}_{\mathrm{j}}=\ln \left(\frac{P_{2}}{P_{1}}\right)
$$

Calculate the "average variance" from the average. The calculation of "average variance" can be measured using standard deviation:

$$
\overline{\mathrm{SD}}=\sqrt{\frac{\sum(X-X)^{2}}{n}}
$$

Calculate the annualized volatility:

$$
\text { Annualized volatility }=S D^{*} \sqrt{12}
$$

Analysis of Volatility Spillover. In analyzing the volatility spillover used the GARCH BEKK-models to uncover the volatility spillover between prices at the level of farmers and consumers. The following GARCH BEKK- model used to analyze price volatility in the level of the farmer and price at the consumer level:

$$
\mathrm{hCP}, \mathrm{PP}_{\mathrm{t}}=\mathrm{CCP}, \mathrm{PP}+\alpha_{C P, P P}^{2} v_{C P_{t}-1}^{2} v_{P P_{t}-1}^{2}+\beta_{C P, P P}^{2} \mathrm{hCP}, \mathrm{PPt}-1
$$

Where, $h C P, P P t$ is the conditional covariance relationship between the price of rice at the consumer level and the price of harvested dry grain at the farm level at the time $(t) ; C$ is a constant; $\alpha, \beta$ is the estimation of parameter; $h C P, P P-1$ is the conditional covariance relationship between the price of rice at the consumer level and the price of harvested dry grain at the farm level at a previous period; $v_{C P_{t}-1}^{2} v_{P P_{t}-1}^{2}$ is the squared residual between the price of rice at the consumer level and the price of harvested dry grain at the farm level at a previous period; $P P$ is a variable of price at farmer level; and $C P$ is the consumer price variable. The interrelated market volatility spillover can be known from the squared residual value $\left(v_{P P_{t}-1}^{2} v_{C P_{t}-1}^{2}\right)$ (Rapsomanikis, 2011). If the value of $v_{P P_{t}-1}^{2} v_{C P_{t}-1}^{2}<0$ (negative), It didn't occur volatility spillover between the price of rice at the consumer level and harvested dry grain at the level of the farmer. And If the value of $v_{P P_{t}-1}^{2} v_{C P_{t}-1}^{2}>0$ (positive), then there is volatility spillover between the price of rice at the level of consumers and the price of harvested dry grain at the farm level.

\section{RESULTS AND DISCUSSION}

Result of Price Volatility. The analysis of price volatility is used to indicate the degree of variation of the ups and downs of the price of harvested dry grain at the farmers level and 
rice prices at the consumer level in East Java. Based on table 1, price data at the farmers level and consumers in Jember, Malang, and Kediri has a value of $t_{\text {statistic }}<$ test critical value. This means that the data on the level of the farmer and the consumer are stationary level. Thus, it can be said that the time series data does not contain spurious regression and unit root.

Table 1 - Stationary Test Results of Price Data at the Level of Farmers and Consumers

\begin{tabular}{cccccc}
\hline \multirow{2}{*}{ Variable } & \multirow{2}{*}{ Level } & \multicolumn{4}{c}{ ADF Test } \\
\cline { 3 - 6 } & & Test Critical Value $(\alpha=5 \%)$ & $t_{\text {statistic }}$ & Prob & Stationarity \\
\hline Farmer's price in Jember & Level & $-2,897223$ & $-10,16557$ & 0,0000 & stationary \\
Consumer's Price in Jember & Level & $-2,897223$ & $-9,227915$ & 0,0000 & stationary \\
Farmer's price in Malang & Level & $-2,897223$ & $-6,056026$ & 0,0000 & stationary \\
Consumer's Price in Malang & Level & $-2,898145$ & $-4,641213$ & 0,0003 & stationary \\
Farmer's Price in Kediri & Level & $-2,897223$ & $-9,706081$ & 0,0000 & stationary \\
Consumer's Price in Kediri & Level & $-2,897223$ & $-6,683464$ & 0,0000 & stationary \\
\hline
\end{tabular}

Source: Secondary data (re-make), 2017.

Error tolerance $(\alpha)$ 5\%.

After the data was stationary, the next step was the selection of the most suitable ARMA order based on its tentative model. Based on table 2. The result of the best ARMA order of price at the farmers level in Jember, Malang, and Kediri in a row were the order of ARMA (1.1), the order of ARMA (3.3) and the order of ARMA (3.3). While the results of the best order of ARMA on consumer prices in Jember, Malang, and Kediri in a row were the order of ARMA (3.3), the order of ARMA (3.2) and the order of ARMA (2.2). The result of the best order of ARMA on the prices at the farmers level and consumers will be used in subsequent analysis, i.e. ARCH effect test.

Price variable that is containing $\mathrm{ARCH}$ effect is consumer price variable in Jember and farmer price in Kediri. This was because the value of obs* $\mathrm{R}$-squared on both variables is smaller than $F_{\text {statistic }}$ and the probability is less than 0.05 . Thus, of the six variables of price data that can be analyzed using ARCH / GARCH were the only variable price of rice at the consumer level in Jember and harvested dry grain at the farmer level in Kediri because of $\mathrm{ARCH}$ effect indicates that data is heteroskedasticity and the effect occurred price volatility.

Table 2 - Results of the Best ARMA Order Selection

\begin{tabular}{|c|c|c|c|c|c|c|}
\hline Variable & $\begin{array}{l}\text { ARMA } \\
\text { Model }\end{array}$ & Parameterr & $\begin{array}{l}\text { Parameter } \\
\text { Coefficient }\end{array}$ & $\begin{array}{c}\mathrm{P}- \\
\text { value }\end{array}$ & Significancy & $\begin{array}{c}\text { Standard Error of } \\
\text { Regressor }\end{array}$ \\
\hline Farmer's price Jember & $(1,1)$ & $\begin{array}{c}\mathrm{C} \\
\mathrm{AR}(1) \\
\mathrm{MA}(1)\end{array}$ & $\begin{array}{c}0,001945 \\
0,683907 \\
-0,979948 \\
\end{array}$ & $\begin{array}{l}0,0000 \\
0,0000 \\
\end{array}$ & $\begin{array}{l}\text { Significant } \\
\text { Significant }\end{array}$ & 0,028711 \\
\hline $\begin{array}{l}\text { Consumer's price } \\
\text { Jember }\end{array}$ & $(3,3)$ & $\begin{array}{c}C \\
\text { AR (3) } \\
\text { MA (3) }\end{array}$ & $\begin{array}{c}0.002153 \\
-0,870587 \\
0,960148\end{array}$ & $\begin{array}{l}0,0000 \\
0,0000\end{array}$ & $\begin{array}{l}\text { Significant } \\
\text { Significant }\end{array}$ & 0,016413 \\
\hline Farmer's price Malang & $(3,3)$ & $\begin{array}{c}\mathrm{C} \\
\mathrm{AR}(3) \\
\mathrm{MA}(3)\end{array}$ & $\begin{array}{c}0,002651 \\
-0,459152 \\
0,560647\end{array}$ & $\begin{array}{l}0,0042 \\
0,0016 \\
\end{array}$ & $\begin{array}{l}\text { Significant } \\
\text { Significant }\end{array}$ & 0,022384 \\
\hline $\begin{array}{l}\text { Consumer's price } \\
\text { Malang }\end{array}$ & $(3,2)$ & $\begin{array}{c}C \\
\text { AR (3) } \\
M A(2) \\
\end{array}$ & $\begin{array}{c}0,003088 \\
0,272074 \\
-0,259027 \\
\end{array}$ & $\begin{array}{l}0,0145 \\
0,0216 \\
\end{array}$ & $\begin{array}{l}\text { Significant } \\
\text { Significant }\end{array}$ & 0,015348 \\
\hline Farmer's price Kediri & $(3,3)$ & $\begin{array}{c}C \\
\text { AR (3) } \\
M A(3)\end{array}$ & $\begin{array}{c}0,003080 \\
-0,846097 \\
0,934638 \\
\end{array}$ & $\begin{array}{l}0,0000 \\
0,0000\end{array}$ & $\begin{array}{l}\text { Significant } \\
\text { Significant }\end{array}$ & 0,033637 \\
\hline $\begin{array}{c}\text { Consumer's price } \\
\text { Kediri }\end{array}$ & $(2,2)$ & $\begin{array}{c}C \\
\text { AR (2) } \\
\text { MA (2) }\end{array}$ & $\begin{array}{c}0,002879 \\
-0,435462 \\
0,973440\end{array}$ & $\begin{array}{l}0,0000 \\
0,0000\end{array}$ & $\begin{array}{l}\text { Significant } \\
\text { Significant }\end{array}$ & 0,012318 \\
\hline
\end{tabular}

Source: secondary data (re-make), 2017.

Error tolerance (a) $5 \%$. 
Table 3 - The Result of ARCH Effect Test

\begin{tabular}{cccccc}
\hline Variable & Obs ${ }^{*} R$-squared & Prob & $F_{\text {statistic }}$ & Prob & Arch Effect \\
\hline Farmer price in Jember & 1,983875 & 0,1590 & 1,983470 & 0,1629 & No ARCH effect \\
Consumer price in Jember & 6,107806 & 0,0135 & 6,452009 & 0,0131 & ARCH effect exists \\
Farmer price in Malang & 1,926555 & 0,1651 & 1,924719 & 0,1693 & No ARCH effect \\
Consumer price in Malang & 2,581211 & 0,1081 & 2,600842 & 0,1109 & No ARCH effect \\
Farmer price in Kediri & 12,01234 & 0,0005 & 13,80778 & 0,0004 & ARCH effect exists \\
Consumer price in Kediri & 0,002639 & 0,9590 & 0,002573 & 0,9597 & No ARCH effect \\
\hline
\end{tabular}

Source: secondary data (re-make), 2017.

Error Tolerance (a) $5 \%$.

Value of $\alpha$ is representing an $A R C H$ value, while $\beta$ is the value of the GARCH. The results of the estimation of GARCH model (1.1) in table 4 shows that the price of harvested dry grain at the level of farmers in Kediri with a very high price volatility (extremely high volatility) proven by the value of volatility greater than 1 which the value of $\alpha+\beta>1$, namely 1.356754. While rice price at the consumer level in Jember has a low price volatility (low volatility) proven by the value of volatility that is less than 1 in which the values of $\alpha+\beta<1$, i.e. 0.829743 .

Table 4 - Result of Behavior of Volatility using $\operatorname{GARCH}(1,1)$

\begin{tabular}{|c|c|c|c|c|c|c|c|}
\hline Variable & $C$ & $\alpha$ & Prob & $\beta$ & Prob & $\alpha+\beta$ & Volatility \\
\hline $\begin{array}{c}\text { Farmer price in } \\
\text { Jember }\end{array}$ & - & - & - & - & - & - & $\begin{array}{l}\text { Volatility doesn't } \\
\text { occur }\end{array}$ \\
\hline $\begin{array}{c}\text { Consumer price in } \\
\text { Jember }\end{array}$ & 0,000125 & 0,906381 & 0,0021 & $-0,076637$ & 0,2090 & 0,829743 & Low volatility \\
\hline $\begin{array}{c}\text { Farmer price in } \\
\text { Malang }\end{array}$ & - & - & - & - & - & - & $\begin{array}{c}\text { Volatility doesn't } \\
\text { occur }\end{array}$ \\
\hline $\begin{array}{c}\text { Consumer price in } \\
\text { Malang }\end{array}$ & - & - & - & - & - & - & $\begin{array}{l}\text { volatility doesn't } \\
\text { occur }\end{array}$ \\
\hline $\begin{array}{c}\text { Farmer price in } \\
\text { Kediri }\end{array}$ & 0,000149 & 1,253428 & 0,0003 & 0,103326 & 0,2672 & 1,356754 & $\begin{array}{c}\text { Extremely high } \\
\text { volatility }\end{array}$ \\
\hline $\begin{array}{c}\text { Consumer price in } \\
\text { Kediri }\end{array}$ & - & - & - & - & - & - & $\begin{array}{c}\text { Volatility doesn't } \\
\text { occur }\end{array}$ \\
\hline
\end{tabular}

Source: secondary data (re-make), 2017.

Error tolerance (a) $5 \%$.

The price of harvested dry grain at the farmer's level every month and years was fluctuation. The fluctuation cycle of the price with the same tends to occur each year. In addition, the pattern of grain prices that farmers received inversely proportional to the grain production pattern produced by the farmers. When the grain production is high, the price of grain decreased. And conversely, the low production of grain makes the prices highly increased. These conditions led to high price volatility on the harvested dry grain prices at the level of farmers.

The high price volatility of harvested dry grain also allegedly as the impact of uneffectiveness government policy related to government purchase prices (floor price). This is because the percentage of cases the under minimum grain purchase prices by the Government was still quite high (Arjayanti, 2010). In addition, procurement of rice by Bulog and the determination of cost of goods purchase has not done at the right time. In this case, Bulog would instead perform the lowest amounts of procurement at the time of the harvest months. While the highest procurement precisely in facing famine. Meanwhile, related to the time setting of floor price is precisely done after the great harvest passed so that the determination of the floor price could not be effective because farmers generally have done the harvesting.

Meanwhile, rice prices that were in low volatility could indicate that rice prices at the consumer level tend to be stable. Stability of rice prices may occur due to a pricing policy instrument that was formed by the Government to protect the consumer-level price. A pricing policy instrument of the Government among other things, distributing subsidized rice to the 
poor (Raskin), perform a buffer stock of rice through the purchase of rice yield both produce domestics and imports, and controlling during the turmoil of the market price through the rice price stabilization operations (OSBH) (Prastowo et al., 2008).

The average annualized volatility of the rice price at the consumer level price variations has a smaller value than the variation value at price of dry grain at the level of farmers. This condition indicates that the rice price was more relatively stable than the price of harvested dry grain at the farmer level indicates that the price volatility of rice at the consumer level is low. Rice prices relatively stable occurred because the Government often conducts market operations directly to the consumer market than the farmers market, so high price fluctuations could be directly addressed.

Table 5 - The Development of Annualized Price Volatility at the Farmer Level

\begin{tabular}{ccccccc}
\hline Year & $\begin{array}{c}\text { Farmer price } \\
\text { in Jember }\end{array}$ & $\begin{array}{c}\text { Consumer price } \\
\text { in Jember }\end{array}$ & $\begin{array}{c}\text { Farmer price } \\
\text { in Malang }\end{array}$ & $\begin{array}{c}\text { Consumer price } \\
\text { in Malang }\end{array}$ & $\begin{array}{c}\text { Farmer price } \\
\text { in Kediri }\end{array}$ & $\begin{array}{c}\text { Consumer price } \\
\text { in Kediri }\end{array}$ \\
\hline 2010 & 43,02 & 12,63 & 37,63 & 19,95 & 44,22 & 23,17 \\
2011 & 26,72 & 19,10 & 22,19 & 22,09 & 37,72 & 20,04 \\
2012 & 14,97 & 7,64 & 4,88 & 6,39 & 25,01 & 8,76 \\
2013 & 20,15 & 7,21 & 10,92 & 3,80 & 29,61 & 2,86 \\
2014 & 28,14 & 17,60 & 12,11 & 7,47 & 12,01 & 11,76 \\
2015 & 21,28 & 18,44 & 23,59 & 12,20 & 22,71 & 4,84 \\
2016 & 16,33 & 7,45 & 16,47 & 7,99 & 19,37 & 5,46 \\
\hline Mean & 24,37 & 12,87 & 18,24 & 11,41 & 27,24 & 10,98 \\
\hline
\end{tabular}

Source: secondary data (re-make), 2017.

Result of Volatility Spillover. On the analysis of the previous price volatility, that the price data which has the effect of $\mathrm{ARCH}$ was the harvested dry grain price data at the level of farmers in Jember and rice prices at the consumer level in Kediri. While the harvested dry grain price data at the level of farmers in Jember and Malang, as well as data of rice price at the consumer level in Malang and Kediri, does not contain the ARCH effects and it could not be analyzed using GARCH-BEKK model. So the volatility spillover analysis can only be analyzed between rice prices at the consumer level in Jember and harvested dry grain prices at the level of farmers in Kediri.

Results of Analysis in table 6, shows that the value of $v_{C P_{t}-1}^{2} v_{P P_{t}-1}^{2}$ as much as $(-0.57)$ with the negative sign means that the volatility spillover does not occur between rice prices at the consumer level in Jember and prices of the harvested dry grain at the level of farmers in Kediri. So when the trend changes in the price volatility of rice at the consumer level in Jember will not be followed by a change of harvested dry grain price volatility at the level of farmers in Kediri.

In the short term, the dynamics of rice price at the consumer level commonly has the same pattern with rice price dynamics at the level of farmers because the demand faced by the farmers in farmer's level is a derivative of the demand in the area of consumer (Harianto and Sari, 2011). If the rice price increase in the level of the consumer caused by the high demand so traders will continue rising the rice prices to farmers. So the price at the level of farmers or peasants is also experiencing an increase.

Meanwhile, the conditionals correlation between consumer prices and farmers negatively shows that rates transmission from consumer level to the level of the farmer occurred imperfectly and asymmetric. This condition is caused arising of rice price at consumer level followed by the rise of the price continues to the farmers slowly and imperfectly. So price fluctuations in farmer level higher than price fluctuations in the level of the consumer.

The price transmission occurs from the consumer market to the farmers market happens imperfectly and asymmetric, it can be indicators of the existence of oligopsony or monopsony power on the marketing agencies such as the middleman and merchant. When market traders have oligopsony or monopsony power, then the trader will be able to control the purchase price obtained from farmers so that although rice prices at the consumer level are relatively constant. 
Table 6 - The Result of Annualized Price Volatility Spillover at the Farmer and Consumer Level

\begin{tabular}{ccccc}
\hline Variable & $\mathrm{C}$ & $v_{C P_{t}-1}^{2} v_{P P_{t}-1}^{2}$ & $\begin{array}{c}\mathrm{hCP}, \mathrm{PP} \text { t- } \\
1\end{array}$ & $\begin{array}{c}\text { Volatility spillover } \\
\text { analysis }\end{array}$ \\
\hline $\begin{array}{c}\text { Vol. Consumer price in Jember } \rightarrow \text { Vol. } \\
\text { Farmer price in Jember }\end{array}$ & - & - & - & $\begin{array}{c}\text { Un-analyzed volatility } \\
\text { spillover }\end{array}$ \\
\hline $\begin{array}{c}\text { Vol. Consumer price in Jember } \rightarrow \text { Vol. } \\
\text { Farmer price in Malang }\end{array}$ & - & - & - & $\begin{array}{c}\text { Un-analyzed spillover } \\
\text { volatility }\end{array}$ \\
\hline $\begin{array}{c}\text { Vol. Consumer price in Jember } \rightarrow \text { Vol. } \\
\text { Farmer price in Kediri }\end{array}$ & 0,000098 & $-0,57$ & $-0,10$ & $\begin{array}{c}\text { volatility spillover } \\
\text { doesn't occur }\end{array}$ \\
\hline $\begin{array}{c}\text { Vol. Consumer price in Malang } \rightarrow \text { Vol. } \\
\text { Farmer price in Malang }\end{array}$ & - & - & - & $\begin{array}{c}\text { Un-analyzed volatility } \\
\text { spillover }\end{array}$ \\
\hline $\begin{array}{c}\text { Vol. Consumer price in Malang } \rightarrow \text { Vol. Farmer } \\
\text { price in Jember }\end{array}$ & - & - & - & $\begin{array}{c}\text { Un-analyzed volatility } \\
\text { spillover }\end{array}$ \\
\hline $\begin{array}{c}\text { Vol. Consumer price in Malang } \rightarrow \text { Vol. Farmer } \\
\text { price Kediri }\end{array}$ & - & - & - & $\begin{array}{c}\text { Un-analyzed volatility } \\
\text { spillover }\end{array}$ \\
\hline $\begin{array}{c}\text { Vol. Consumer price in Kediri } \rightarrow \text { Vol. Farmer } \\
\text { price in Kediri }\end{array}$ & - & - & - & $\begin{array}{c}\text { Un-analyzed volatility } \\
\text { spillover }\end{array}$ \\
\hline $\begin{array}{c}\text { Vol. Consumer price in Kediri } \rightarrow \text { Vol. Farmer } \\
\text { price in Jember }\end{array}$ & - & - & - & $\begin{array}{c}\text { Un-analyzed volatility } \\
\text { spillover }\end{array}$ \\
\hline $\begin{array}{c}\text { Vol. Consumer price in Kediri } \rightarrow \text { Vol. Farmer } \\
\text { price in Malang }\end{array}$ & - & - & - & $\begin{array}{c}\text { Un-analyzed volatility } \\
\text { spillover }\end{array}$ \\
\hline
\end{tabular}

Source: secondary data (re-make), 2017.

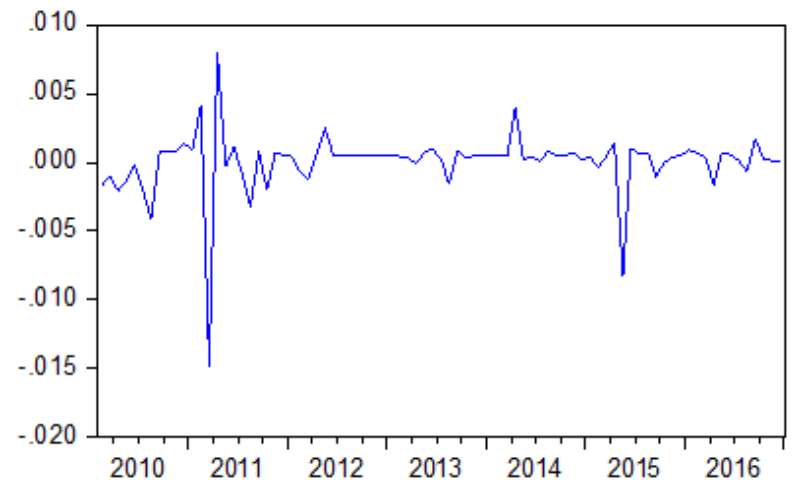

Figure 2 - Chart of Conditional Covariance

Spillover Volatility of rice price at the consumer level in Jember and harvested dry grain price at the farmer level in Kediri

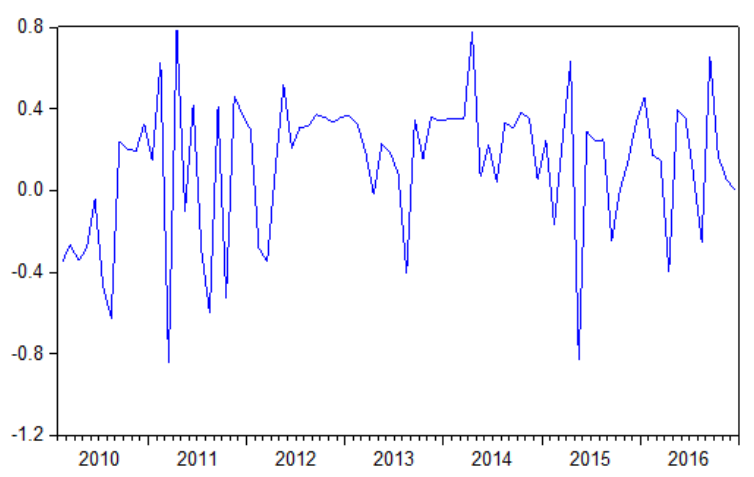

Figure 3 - Chart of Conditional Correlation price Volatility of rice at the consumer level in Jember and price of harvested dry grain at the farmer level in Kediri

But the middleman or trader can press the purchase price from the farmers to maximise its profits (Irawan, 2007). And vice versa, when rising prices at the consumer level, the trader or the middleman or trader keep the prices up imperfectly to the farmers so as to increase the price received by the farmers is lower to be compared with the increase of the price that occurs at the consumer level.

\section{CONCLUSION AND RECOMMENDATIONS}

Based on the results of the research, the conclusions of this study, that price volatility of harvested dry grain are included an extremely high volatility (price volatility is very high) category. While the price volatility of rice at the consumer level are included in the low volatility (low volatility) category. In addition, the volatility spillover does not occur between the consumer market and farmers market because the results of the analysis show that squared residual marked negatively.

In order to cope with the onset of price volatility in the level of the farmer and the consumer, the need for a balanced policy between the farmers and the consumers in a way guaranteeing the effective price floor and market information disclosure related to the commodity prices in order to make the pattern of price transmission of interrelated market symmetrical. 


\section{REFERENCES}

3. Arjayanti, Syam. 2010. Analisis Kebijakan Stabilisasi Harga Gabah/Beras di Tingkat Petani di Propinsi DIY. Volume 15 Nomor 2. Jurnal Kebijakan dan Administrasi Publik. Jogjakarta.

4. Assefa, Tsion Taye; Meuwissen, Miranda P.M.; dan Lansink, Alfons G.J.M. Oude. 2015. Does Price Volatility Matter? An Assessment along EU Food Chains. International Conference of Agricultural Economist. Italia.

5. Badan Penelitian dan Pengembangan Pertanian. 2012. Dinamika Produksi dan Harga Beras di Indonesia. Kementrian Pertanian.

6. Badan Pengkajian dan Pengembangan Kebijakan Perdagangan. 2015. Analisis Dampak Kebijakan Pemerintah Terhadap Inflasi dan Kemiskinan. Kementrian Perdagangan. Jakarta.

7. Banterle, Alessandro; dan Vandone, Daniela. 2013. Price Volatility and Risk Management: The Case of Rice. Universität Bonn-ILB Press, Bonn. Jerman.

8. Connor, O. Declan; dan Keane, Michael. 2011. Empirical Issues Relating to Diary Commodity Price Volatility. Spinger Science+Business Media, LLC. USA.

9. Demeke, Mulat; Dewe, David; Tefft, James; Ferede, Tadele; dan Bell, Winnie. 2012. Stabilizing Price Incentives for Staple Grain Producers in the Context of Broader Agricultural Policies. ESA Working Paper No. 12-05. Food And Agriculture Organization of the United Nations.

10. Demeke, Mulat dan Balie, Jean. 2016. Assessment of National Policies in Developing Countries to Combat and Mitigate Effect of Agricultural Markets' Excessive Price Volatility. Routledge Taylor \& Francis Group. London and New York.

11. Donmez, Ayca dan Magrini, Emiliano. 2013. Agricultural Commodity Price Volatility and its Macroeconomic Determinats. JRC Thechnical Reports.

12. Ekananda, Mahyus. 2016. Analisis Ekonometrika Time Series, Edisi 2. Mitra Wacana Media. Jakarta.

13. FAO, IFAD, IMF, OECD, UNCTAD, WFP, World Bank, dan WTO. 2011. Price Volatility in Food and Agricultural Markets: Policy Responses. Diakses http://g20india.gov.in/hindi/pdfs/2011-B-June-Joint-Report-on-Food-Price.pdf.

14. Gilbert, C.L dan Morgan, C. W. 2010. Food Price Volatility. Royal Society.

15. Harianto dan Lianita, Dina Sari. 2011. Pola Spread Harga Gabah dan Beras di Indonesia: Suatu Indikasi Efektivitas Perubahan Kelembagaan Bulog. Departemen Agribisnis Fakultas Ekonomi dan Manajemen, Institut Pertanian Bogor. Bogor.

16. Irawan, Bambang. 2007. Fluktuasi Harga, Transmisi Harga dan Pemasaran Sayuran dan Buah. Analisis Kebijakan Pertanian. Volume 5 No. 4: 358-373. Bogor.

17. Jamal, Erizal; Noekman, N. Khairina; Hendiarto; Ariningsih, Ening; dan Askin, Andi. 2006. Analisis Kebijakan Penentuan Harga Pembelian Gabah. Pusat Analisis Sosial Ekonomi dan Kebijakan Pertanian. Departemen Pertanian.

18. Kalkuhl, Mathias; Kornher, Lukas; Kozicka, Marta; Boulanger,Pierre; dan Torero, Maximo. 2013. Conceptual Framework on Price Volatility and its Impact o Food and Nutrion Security in the Short Time, Foodsecure working paper No. 15. Interdisciplinary Research Project to Explore the Future of Global Food and Nutrion Security.

19. Kant, Ravi Jain. 2001. Putting Volatility to Work. Active Trader.

20. Ledebur, Von O. dan Schmitz, J. 2012. Price Volatility and Farm Income Stabilisation, Modelling Outcomes and Assessing Market and Policy Based Responses. Paper prepared for the 123rd EAAE Seminar. Dublin.

21. Lipetit, Plot Isabelle. 2011. Price Volatility and Price Leadership in the EU Beef and Pork Meat Market. Spinger Science+Business Media, LLC. USA.

22. Moledina, A. Amyaz; Roe, L. Terry; dan Shane, Mathew. 2004. Measuring Commodity Price Volatility and the Welfare Consequences of Eliminating Volatility. Working Paper, USDA/ERS and the Economic Development Center. University of Minnesota. 
23. Prastowo, Joko Nugroho; Yanuarti, Tri; dan Depari, Yoni. 2008. Pengaruh Distribusi Dalam Pembentukan Harga Komoditas dan Implikasinya Terhadap Inflasi. Working Paper. Bank Indonesia.

24. Rapsomanikis, George. 2011. Price Transmission and Volatility Spillovers in Food Markets, Chapter 8. Food and Agriculture Organization of the United Nations. Rome.

25. Serra, Teresa dan Gil, José M. 2012. Price Volatility in Food Markets: Can Stock Building Mitigate Price Fluctuations?. International Association of Agricultural Economists (IAAE) Triennial Conference. Brazil.

26. Singh, Ranjit; dan Kumar,Amit. 2015. Stock Trading Strategy Based on Daily Stock Volatility. IJCST Vol. 6, Iss ue 1 Spl- 1.

27. Tomek, G. William dan Robinson, L. Kenneth. 1990. Agricultural Product Price. Cornel University Press. New York. 